\title{
Production of desert rose seedlings in different potting media ${ }^{(1)}$
}

\author{
RONAN CARLOS COLOMBO(2)*, VANESSA FAVETTA(2), DEIVED UILIAN DE CARVALHO(2), MARIA APARECIDA DA \\ CRUZ $^{(2)}$, SERGIO RUFFO ROBERTO(2), RICARDO TADEU DE FARIA(2)
}

\begin{abstract}
Over the past decade the desert rose received fame in the flower market due to its striking and sculptural forms; however, the commercial production of these species is quite recent and little is known about its crop management, including substrates recommendation. The objectives of this study were to investigate the effect of different substrates on desert rose seed germination and production of its seedlings. Experiment I: freshly harvested seeds of desert rose were sown in different substrates e.g. sand, coconut fiber, semi-composted pine bark, sand + coconut fiber, semi-composted pine bark + sand and coconut fiber + semicomposted pine bark. These substrates were evaluated to study the emergence percentage of seeds, initial growth of seedlings and seedling emergence speed index (ESI). Experiment II: desert rose from the experiment I were transferred to plastic pots filled with the same substrates as in experiment I. The $\mathrm{pH}$ and electrical conductivity (EC) of the substrates were noted every 30 days while the growth parameters of seedlings were recorded after 240 days. Results from experiment I showed higher germination rate and seedling growth in substrates containing semi-composted pine bark. Similarly, in experiment II, better quality seedlings were observed in substrates containing semi-composted pine bark. Thus, for desert rose seed germination and seedling growth, it is recommended to use substrates containing semi-composted pine bark.
\end{abstract}

Keywords: Adenium obesum, seeds, germination, Apocynaceae.

\section{RESUMO}

Produção de mudas de rosa do deserto em diferentes substratos

Na última década as plantas de rosa do deserto ganharam destaque no mercado de flores devido ao seu exotismo e formas esculturais; contudo, a produção comercial dessa espécie ainda é recente e pouco se sabe sobre o manejo da cultura, incluindo a recomendação de substratos. Assim, objetivou-se investigar o efeito de diferentes substratos na germinação das sementes e produção de mudas de rosa do deserto. Experimento I: sementes recém-colhidas de rosa do deserto foram semeadas nos substratos: areia, fibra de coco, casca de pinus semi-compostada, areia + fibra de coco, areia + casca de pinus semi-compostada e fibra de coco + casca de pinus semi-compostada. Os parâmetros estudados neste ensaio incluíram a porcentagem de emergência das sementes e índice de velocidade de emergência (IVE), e o crescimento inicial das mudas. Experimento II: plantas de rosa do deserto provenientes do experimento I foram transplantadas para potes plásticos preenchidos com os mesmos substratos empregados no experimento I. O pH e a condutividade elétrica dos substratos (CE) foram medidos a cada 30 dias enquanto os parâmetros de crescimento foram tomados depois de 240 dias de cultivo. No experimento I maiores porcentagens de germinação e crescimento das mudas foram observados nos substratos contendo casca de pinus semi-compostada. Similarmente, no experimento II, mudas de melhor qualidade foram encontradas nesses mesmos substratos. Assim, para a germinação de sementes e crescimento de mudas de rosa do deserto é recomendado o emprego de substratos contento casca de pinus semi-compostada.

Palavras-chave: Adenium obesum, sementes, germinação, Apocynaceae.

\section{INTRODUCTION}

Adenium genus belongs to the botanical family Apocynaceae, which includes many tropical ornamental species such as Catharanthus spp., Beaumontia spp., Carissa spp., Allamanda spp., Mandevilla spp., Nerium spp. and Plumeria spp. (COLOMBO et al., 2015). Adenium obesum (Forssk.) Roem. \& Schult. was found in the subSaharan region of Africa, from Sudan to Kenya and west of Senegal to south of Natal and Swaziland (DIMMITT et al., 2009). These species are caudiciform, which develops roots and/or swollen stem that serve as primary organ to reserve water. The flowers having five sepals and five petals of various shades that are fused together into a floral tube (DIMMITT et al., 2009; McBRIDE et al., 2014). However, despite the great floral diversity, the plant is mostly valued for the shape and development of its caudex. The plant is commercialized in vases or other similar containers in the form of seedlings or flowering plants. Therefore, to provide physical and chemical support and to ensure better seed germination and seedling development, the use of appropriate substrate is of utmost importance for the production of these species on a large scale. 
Different types of substrates are being used for the production of ornamental plants. But in order to obtain satisfactory results, it is important to characterize its physical and chemical properties, which play a key role during the potting stages (PACHECO, 2006; SCHAFER et al., 2008; SCHAFER et al., 2015). The proportions of air/water of a substrate are determined by their physical properties, mainly the density and porosity of each material (KÄMPF et al., 2006; SANTOS et al., 2002; SCHAFER et al., 2015). This property may directly affect the seed germination, since the density and porosity of the substrate are related to the availability of water and air to the medium, and may provide greater or lesser resistance to seedling emergence.

Among chemical properties of the material or mix (substrate), $\mathrm{pH}$ and electrical conductivity (EC) holds great importance (KÄMPF et al., 2006; LUDWIG et al., 2014). Constant monitoring of these properties provides the growers an overview of the salinization and acidification of the growth medium, thus making it possible to fertilize substrates without damaging of the growth of the seedlings.

Kämpf et al. (2006) and Caballero et al. (2007) reported that the $\mathrm{pH}$ of the substrates is directly related to the availability of nutrients for plants, as well as by complexation and adsorption nutrients reaction. Keeping in view the above facts, this study was designed aiming to evaluate the effect of organic and mineral substrates on seed germination and seedling production of desert rose plants.

\section{MATERIAL AND METHODS}

The experiments were conducted between May to August of 2014 (Experiment I) and from August to April of 2015 (Experiment II) in greenhouse Van der Hoeven ${ }^{\circledR}$, which is covered with polycarbonate plates and humid cooling system. When the internal temperature reaches $28^{\circ} \mathrm{C}$ the cooling system is triggered on and is switched off automatically when temperature reaches $26^{\circ} \mathrm{C}$. The greenhouse is located at the Department of Agronomy in the Londrina State University - UEL.

\section{Experiment I}

Freshly harvested seeds of Adenium obesum were subjected to germination test at $25{ }^{\circ} \mathrm{C}$, using four replicates of 50 seeds, which were placed on blotting paper moistened with distilled water 2.5 times the dry matter of the paper (BRASIL, 2009), packed in crystal polystyrene boxes $\left(G^{2}\right.$ rbox $\left.{ }^{\circledR}\right)$. The variables evaluated were germination percentage and germination speed index (GSI) (MAGUIRE, 1962); the counting was initiated three days after installation. From this test, there was observed that the germination percentage and GSI were $96 \%$ and 8.1 , respectively.

For the emergence test, a completely randomized design was used with 4 replications and 40 seeds per treatment. Seeds were sown in trays with 128 cells, filled with the substrates: sand, coconut fiber Amafibra ${ }^{\circledR} 47$, semi-composted pine bark Lupa ${ }^{\circledR}$, sand + coconut fiber Amafibra $^{\circledR} 47$, semi-composted pine bark Lupa ${ }^{\circledR}+$ Sand,

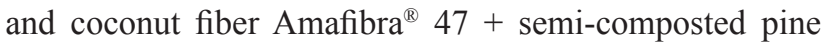
bark Lupa ${ }^{\circledR}$. The sand had an average particle size of 0.2 $0.6 \mathrm{~mm}$ and the substrates mixtures were prepared with a ratio of $1: 1(\mathrm{v} / \mathrm{v})$; substrates physicochemical characteristics was evaluated according to Kämpf et al. (2006) (Table 1). Seedling emergence was recorded on daily basis until it stopped. The recorded data was used to calculate the emergence percentage and emergence speed index (ESI).

Table 1. Physical and chemical characterization of the substrates, based on apparent density (AD), water holding capacity (WHC), pH and electrical conductivity (EC).

\begin{tabular}{|c|c|c|c|c|}
\hline Substrates $^{\mathbf{a}}$ & $\mathbf{A D}\left(\mathbf{g} \mathbf{L}^{-\mathbf{1}}\right)$ & $\mathbf{W H C}\left(\mathbf{m L} \mathbf{L}^{-\mathbf{1}}\right)$ & $\mathbf{p H}$ & $\mathbf{E C}\left(\mathbf{m S ~ \mathbf { ~ m } ^ { - 1 }}\right)$ \\
\hline S & $1,380.0$ & 527.1 & 6.8 & 0.1 \\
\hline CF & 103.6 & 732.4 & 6.2 & 0.3 \\
\hline PB & 274.4 & 378.7 & 4.7 & 2.3 \\
\hline S+CF & 838.0 & 497.5 & 5.8 & 0.2 \\
\hline S+PB & $1,026.0$ & 441.0 & 7.2 & 1.9 \\
\hline CF+PB & 273.3 & 486.3 & 6.7 & 1.7 \\
\hline
\end{tabular}

a Substrate: (S) sand, (CF) coconut fiber, $(\mathrm{PB})$ semi-composted pine bark, $(\mathrm{S}+\mathrm{CF})$ sand + coconut fiber, $(\mathrm{S}+\mathrm{PB})$ sand + semi-composted pine bark and $(\mathrm{CF}+\mathrm{PB})$ coconut fiber + semi-composted pine bark.

After 90 days of last emergence, 10 plants from each treatment with a total of 40 plants per replication, were used to evaluate the different parameters e.g. number of leaves, diameter of the caudex (mm), caudex and taproot length $(\mathrm{mm})$, fresh and dry matter $(\mathrm{g})$ of roots, stems and leaves. The data was subjected to analysis of variance (ANOVA) and means compared by Tukey test at 5\% probability level.

\section{Experiment II}

A. obesum plants from the first experiment (see the plants size in Table 2) were grown in black plastic pots with volume of $0.4 \mathrm{~L}$ filled with the same substrates which the plants germinated in experiment I. The pots were randomly placed on a high bench $(60 \mathrm{~cm})$ and irrigated daily to maintain the water holding capacity of the substrate between 80 and $90 \%$. 
The $\mathrm{pH}$ and electrical conductivity (EC) of the respective treatments were recorded every 30 days using the leaching method (KÄMPF et al., 2006), and every fifth day after these evaluation the plants were fertigated with Hoagland solution at the rate of $50 \mathrm{~mL}$ per pot.

The plant growth was recorded after 240 days, on the basis of shoot height $(\mathrm{cm})$, caudex diameter $(\mathrm{mm})$, number of buds and dry matter of roots, stems and leaves $(\mathrm{g})$. The data from $\mathrm{pH}$ and EC of the substrates were subjected to ANOVA and analyzed by polynomial regression model. The variables related to plant growth were submitted to ANOVA and means compared by Tukey test at $5 \%$ probability.

\section{RESULTS AND DISCUSSION}

\section{Experiment I}

The effect of substrates on seedling emergence percentage and emergence speed index (ESI) are presented in Table 2. Lowest average values of emergence percentage were recorded in the substrates of coconut fiber $(\mathrm{CF})$ and sand + coconut fiber $(\mathrm{S}+\mathrm{CF})$ compared with other substrates, which promoted more than $91 \%$ of germination. These results corroborate to the data obtained in the germination test, in which there was observed $96 \%$ of germination. Despite to have observed higher germination for this species, if the chosen substrate is not adequate, the germination percentage may be decreased.

Table 2. Emergence percentage (EM), emergence speed index (ESI), dry matter of roots (DMR), leaves (DML), stems (DMS), number of leaves (NL), diameter of the caudex (DC), caudex length (CL) and taproot length (TRL) of Adenium plants after 90 days of germination.

\begin{tabular}{|c|c|c|c|c|c|c|c|c|c|c|}
\hline Substrate $^{a}$ & \multicolumn{2}{|c|}{ EM (\%) } & \multicolumn{2}{|c|}{ ESI } & \multicolumn{2}{|c|}{ DMR (g) } & \multicolumn{2}{|c|}{ DML (g) } & \multicolumn{2}{|c|}{ DMS (g) } \\
\hline S & 91 & $a b^{b}$ & 6.22 & $\mathrm{a}$ & 0.013 & d & 0.013 & b & 0.070 & $\mathrm{~b}$ \\
\hline $\mathrm{CF}$ & 84 & b & 4.09 & $\mathrm{~b}$ & 0.023 & $\mathrm{bc}$ & 0.028 & $\mathrm{a}$ & 0.117 & $a b$ \\
\hline PB & 97 & $\mathrm{a}$ & 5.45 & $a b$ & 0.030 & $a b$ & 0.028 & a & 0.137 & $\mathrm{a}$ \\
\hline $\mathrm{S}+\mathrm{CF}$ & 83 & $\mathrm{~b}$ & 4.92 & $a b$ & 0.020 & $\mathrm{~cd}$ & 0.020 & $a b$ & 0.097 & $a b$ \\
\hline $\mathrm{S}+\mathrm{PB}$ & 93 & $a b$ & 5.61 & $a b$ & 0.032 & a & 0.023 & $a b$ & 0.127 & $\mathrm{a}$ \\
\hline $\mathrm{CF}+\mathrm{PB}$ & 98 & a & 5.37 & $a b$ & 0.018 & $\mathrm{~cd}$ & 0.020 & $a b$ & 0.107 & $a b$ \\
\hline CV (\%) & \multicolumn{2}{|c|}{5.52} & \multicolumn{2}{|c|}{14.38} & \multicolumn{2}{|c|}{18.14} & \multicolumn{2}{|c|}{24.33} & \multicolumn{2}{|c|}{20.83} \\
\hline $\mathrm{F}$ & \multicolumn{2}{|c|}{$6.20^{* *}$} & \multicolumn{2}{|c|}{$3.55^{*}$} & \multicolumn{2}{|c|}{$13.80^{* *}$} & \multicolumn{2}{|c|}{$4.56^{* *}$} & \multicolumn{2}{|c|}{$4.42^{* *}$} \\
\hline
\end{tabular}

\begin{tabular}{|c|c|c|c|c|c|c|c|}
\hline Substrate $^{\mathrm{a}}$ & \multicolumn{2}{|c|}{ NL } & \multicolumn{2}{|c|}{$\mathbf{D C}(\mathbf{m m})$} & \multicolumn{2}{|c|}{$\mathbf{C L}(\mathbf{m m})$} & \multicolumn{2}{|c|}{ TRL (cm) } \\
\hline S & 5.10 & $\mathrm{~d}^{\mathrm{b}}$ & 9.61 & $\mathrm{c}$ & 27.11 & $\mathrm{c}$ & 4.84 \\
\hline $\mathrm{CF}$ & 7.20 & $\mathrm{~b}$ & 10.34 & $\mathrm{bc}$ & 31.83 & $\mathrm{a}$ & 4.74 \\
\hline $\mathrm{PB}$ & 8.70 & $\mathrm{a}$ & 11.26 & $\mathrm{a}$ & 32.51 & $\mathrm{a}$ & 5.19 \\
\hline $\mathrm{S}+\mathrm{CF}$ & 6.63 & $\mathrm{bc}$ & 10.41 & $\mathrm{abc}$ & 27.86 & $\mathrm{c}$ & 5.24 \\
\hline $\mathrm{S}+\mathrm{PB}$ & 8.35 & $\mathrm{a}$ & 10.57 & $\mathrm{ab}$ & 31.53 & $\mathrm{ab}$ & 4.74 \\
\hline $\mathrm{CF}+\mathrm{PB}$ & 6.13 & $\mathrm{c}$ & 9.60 & $\mathrm{c}$ & 29.21 & $\mathrm{bc}$ & 4.83 \\
\hline $\mathrm{CV}(\%)$ & & 17.95 & 13.74 & 12.88 & 17.61 \\
\hline F & $46.73^{* *}$ & $7.87^{* *}$ & $13.68^{* *}$ & $2.78^{\mathrm{ns}}$ \\
\hline
\end{tabular}

a Substrate: (S) sand, (CF) coconut fiber, (PB) semi-composted pine bark, (S+CF) sand + coconut fiber, (S+PB) sand + semi-composted pine bark and $(\mathrm{CF}+\mathrm{PB})$ coconut fiber + semi-composted pine bark. ${ }^{b}$ Means followed by the same letter do not differ by Tukey test at $5 \%$ probability. ${ }^{* *}$, ${ }^{*}$ Significant at 1 or $5 \%$ by $\mathrm{F}$ test, respectively.

Wagner Junior et al. (2006) reported that like temperature, the substrate can also influence the process of imbibition and germination due to its effect on the water potential and heat conduction capacity. Furthermore, the seeds emergence occurs more unevenly when the substrate is not ideal, which may be confirmed by the smaller ESI values observed. The ESI in the sand substrate (6.2) was closer to the GSI seen in the germination test $(8.1)$ at $25^{\circ} \mathrm{C}$ on paper. Though, smaller ESIs were expected than GSI, since germination on paper is checked in advance; whereas germination tests in trays with substrates, should expect the seedlings emergence to record the germination.

Thus, the choosing of substrate should depend on the seed requirements e.g. its size, water requirement, light sensitivity and ease to handle seedlings count and other evaluations (BRASIL, 2009). Lowest values of dry matter 
of roots, caudex and leaves were recorded when sand substrate was used, which is also similar to the values from other substrates. The lowest values of these parameters for the sand substrate might be due to the fact that it is considered an inert material, and also during this period there was not applied fertilizer to the substrate, resulting in lowest dry matter of seedlings. Similar results were observed for leaf number, length and diameter of caudex.

On the other hand, organic substrates pure or in mixture, which consisted in semi-composted pine bark e.g. Lupa ${ }^{\circledR}$ and coconut fiber, tend to tolerate absence of chemical fertilization for a longer period of time, ensuring a satisfactory seedlings growth. Despite to have showed similarity to others substrates, the semi-composted pine bark promoted higher caudex growth in length and diameter, as well as the number of leaves (Table 2). This may be related to the physical characteristics of the material (density $=274.4 \mathrm{~g} \mathrm{~L}^{-1}$ and retention capacity of water $=378.7 \mathrm{~mL} \mathrm{~L}^{-1}$ ) and supply of some nutrients due to its decomposition.

In contrast, the coconut fiber is practically inert and does not have the essential nutrients for the seedlings development. However, it presents some unique physical properties that make it a better choice, such as high porosity $(95.6 \%)$, higher water retention capacity $(538 \mathrm{~mL}$ $\mathrm{L}^{-1}$ ) and aeration (45.5\%), along to some other advantages as low cost and wide availability in the northeast region of Brazil (CARRIJO et al., 2002).

The tap root length (Table 2) was not significantly affected by the substrates. This might have occurred because of the seedlings were grown in suspended trays with a hole beneath for excess water drainage, so the roots might have ceased growth due to light and wind coming through the hole. However, Pacheco et al. (2006) observed that the substrates sand, vermiculite and coconut powder provided greater root development for Myracrodruon urundeuva seedlings.

\section{Experiment II}

After 240 days of seedlings planting on the same substrates as used in the Experiment I, the seedlings were evaluated aiming to determine the best substrate that can be used for desert rose propagation during this period. The number of shoots varied from 3.7 to 6 shoots per plant with no significant difference between the substrates (Table 3). This is an important character, since each bud (branch) can produce a whole inflorescence providing higher market value to the plant.

Table 3. Number of buds (NB), shoot height (SH), diameter of caudex (DC), dry matter of leaves (DML), stems (DMS) and roots (DMR) of Adenium plants after 240 days of cultivation

\begin{tabular}{|c|c|c|c|c|c|c|c|c|c|c|c|c|}
\hline Substrate $^{\mathrm{a}}$ & \multicolumn{2}{|l|}{ NB } & \multicolumn{2}{|c|}{ SH (cm) } & \multicolumn{2}{|c|}{ DC (mm) } & \multicolumn{2}{|c|}{ DML (g) } & \multicolumn{2}{|c|}{ DMS (g) } & \multicolumn{2}{|c|}{ DMR (g) } \\
\hline $\mathrm{S}$ & 3.71 & ns & 9.66 & $d^{b}$ & 31.90 & $\mathrm{c}$ & 0.45 & d & 3.12 & $\mathrm{c}$ & 0.43 & $\mathrm{~b}$ \\
\hline $\mathrm{CF}$ & 6.00 & & 12.93 & bc & 35.80 & bc & 1.01 & bc & 6.82 & $a b$ & 1.14 & $a b$ \\
\hline PB & 3.88 & & 15.71 & b & 35.48 & bc & 1.30 & $a b$ & 7.82 & $\mathrm{a}$ & 0.92 & $a b$ \\
\hline $\mathrm{S}+\mathrm{CF}$ & 5.14 & & 12.39 & $\mathrm{~cd}$ & 32.45 & $\mathrm{c}$ & 0.79 & $\mathrm{~cd}$ & 4.18 & $\mathrm{bc}$ & 0.62 & b \\
\hline $\mathrm{S}+\mathrm{PB}$ & 4.29 & & 14.71 & bc & 42.84 & $a b$ & 1.27 & $a b$ & 6.94 & $a$ & 0.84 & $a b$ \\
\hline $\mathrm{CF}+\mathrm{PB}$ & 5.71 & & 19.29 & $\mathrm{a}$ & 43.80 & $\mathrm{a}$ & 1.47 & $\mathrm{a}$ & 8.84 & $\mathrm{a}$ & 1.55 & $a$ \\
\hline CV (\%) & 49.00 & & 13.10 & & 12.73 & & 25.32 & & 27.3 & & 50. & \\
\hline F & $1.20^{\mathrm{ns}}$ & & 22.07 & & $8.27^{* *}$ & & 14.40 & & 11.34 & & 5.10 & \\
\hline
\end{tabular}

${ }^{a}$ Substrate: (S) sand, (CF) coconut fiber, (PB) semi-composted pine bark, (S+CF) sand + coconut fiber, $(\mathrm{S}+\mathrm{PB})$ sand + semi-composted pine bark and $(\mathrm{CF}+\mathrm{PB})$ coconut fiber + semi-composted pine bark. ${ }^{\mathrm{b}}$ Means followed by the same letter do not differ by Tukey test at $5 \%$ probability. ns: differences not significant. ${ }^{* *}$ Significant at $1 \%$ by $\mathrm{F}$ test.

Based on the studied parameters the seedlings grown on sand showed an overall lower growth rate, even before fertilization of the substrate. The shoot height of plants grown in coconut fiber + semi-composted pine bark $(\mathrm{CF}+\mathrm{PB})$ was found about double that of plants grown in sand (Table 3 ). Maximum caudex diameter was observed in this same substrate $(\mathrm{CF}+\mathrm{PB})$, as well as, in the substrate mixture of sand + semi-composted pine bark. This is an important feature, which provides the commercial and ornamental value for the desert rose (COLOMBO et al., 2016).

The data relating to the dry matter of leaves, stems and roots also indicate that the rate of plant growth is influenced by the substrates used (Table 3 ). The substrate mixture of
$\mathrm{CF}+\mathrm{PB}$ resulted in the highest average variables (Figure $1 \mathrm{~F})$, hence it can be assumed that organic mixtures are better suited to the organic-mineral (Figure 1B to D) for desert rose growth, like shown in figure 1, whereas the plants cultivated in sand presented a lowest development (Figure 1A), even when submitted to fertigation. However, these results are still contradictory, Colombo et al. (2016) observed that desert rose grown on coconut fiber + sand $\left(1: 1, \mathrm{~V} \mathrm{v}^{-1}\right)$ and coconut fiber + vermiculite $\left(1: 1, \mathrm{~V} \mathrm{v}^{-1}\right)$ presented better growth rates. On the other hand, Alves et al. (2016) found more effective results when desert rose was grown on the mixture of decomposed pine bark + sand $\left(1: 1, \mathrm{~V} \mathrm{v}^{-1}\right)$. 


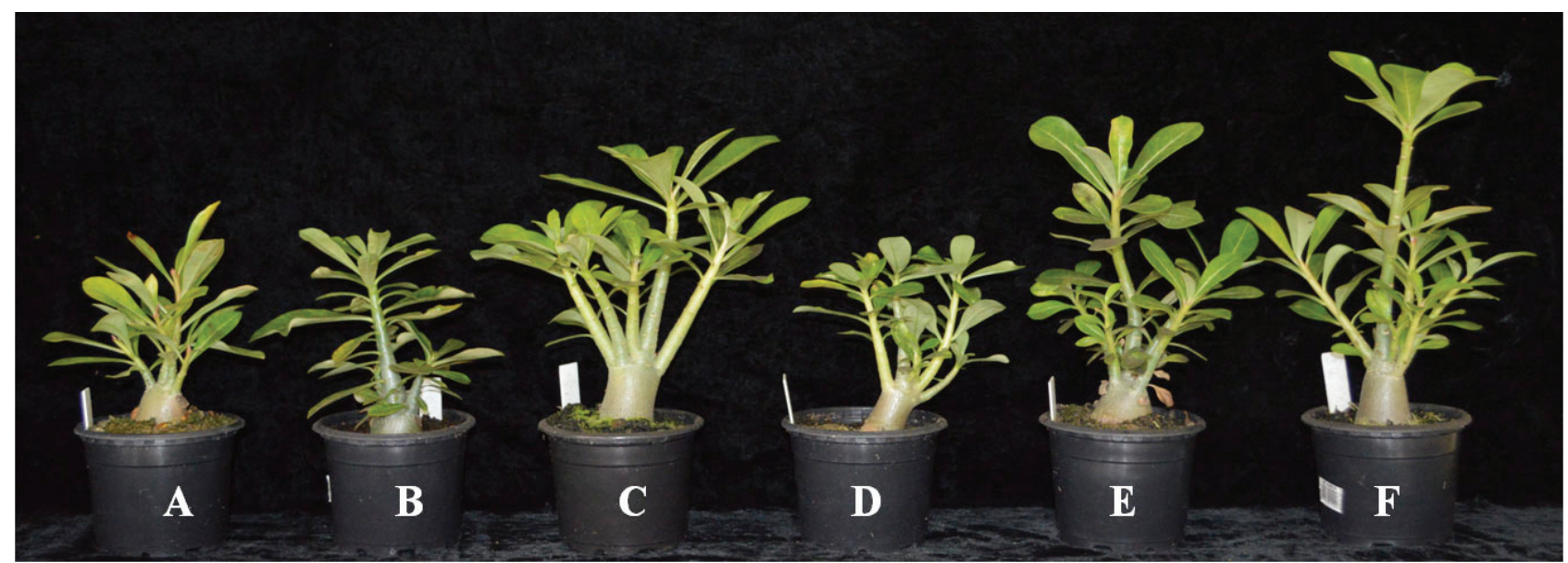

Figure 1. Adenium plants growing on different substrates: (A) sand - S; (B) coconut fiber - CF;

(C) semi-composted pine bark - PB; (D) sand + coconut fiber - S+CF; (E) sand + semi-composted pine bark - S+PB and (F) coconut fiber + semi-composted pine bark $-\mathrm{CF}+\mathrm{PB}$, after 240 days of cultivation

The availability of nutrients in organic substrates is one of the main factors that influences the plants growth. However, it is noteworthy that this does not just depend on the composition of the substrate, but also on the adsorption capacity, $\mathrm{pH}$, biological stability and presence of dissolved organic compounds (CABALLERO et al., 2007). It can be observed from the figure $2(\mathrm{C}, \mathrm{E}$ and $\mathrm{F})$ that $\mathrm{EC}$ showed similar results in pine bark substrate and in its mixtures, with a significant decrease until 90 days of culture, balancing and subsequently decreasing at the end of the cycle. It is likely that the applied dosage of nutrient was not suitable for desert rose, so that plants also absorbed ions present in the substrates and led the EC values below 0.3 $\mathrm{mS} \mathrm{cm}^{-1}$ for all the substrates.
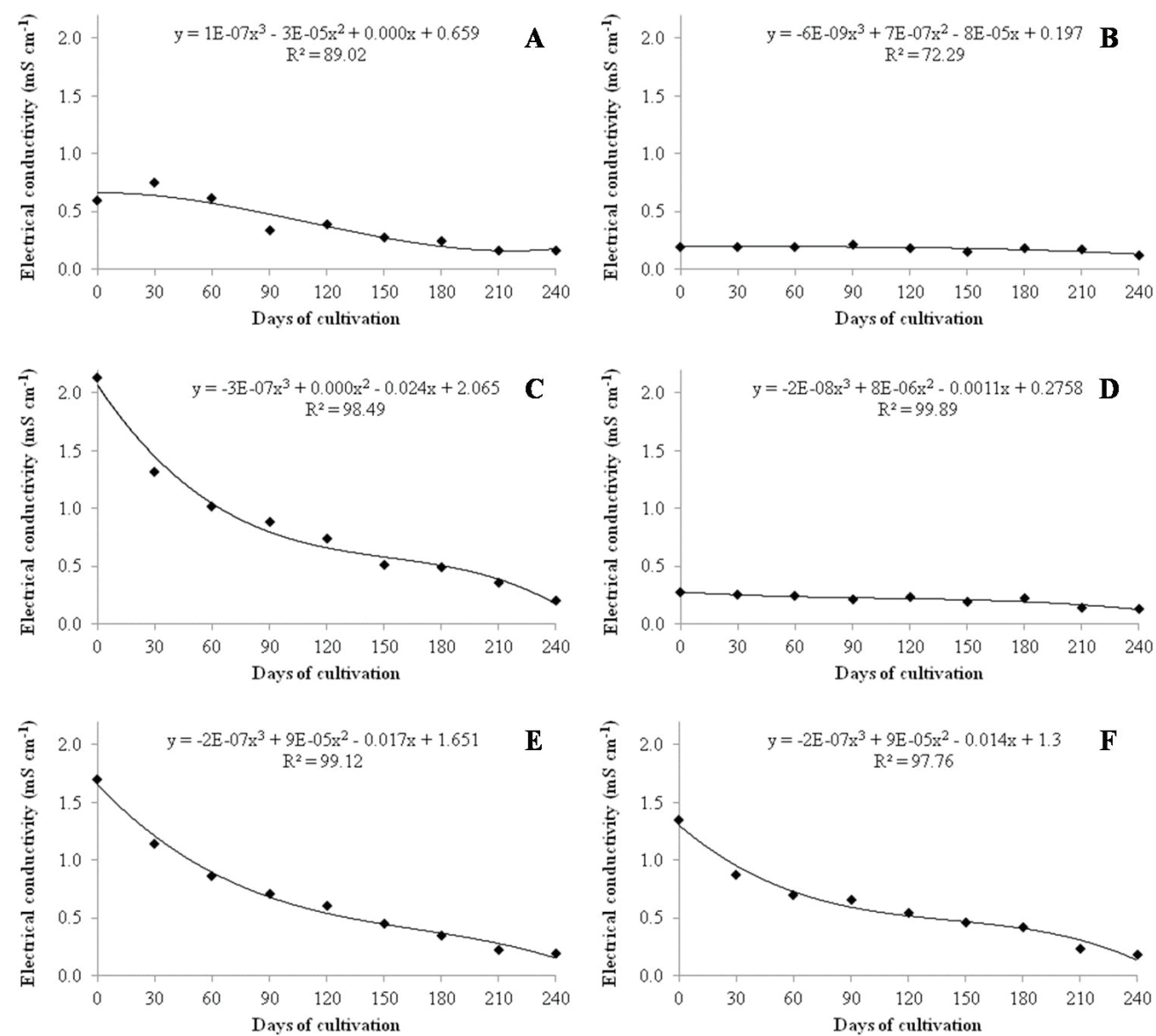

Figure 2 - Variation of electrical conductivity in different substrates: (A) sand - S; (B) coconut fiber - CF; (C) semicomposted pine bark - PB; (D) sand + coconut fiber - S+CF; (E) sand + semi-composted pine bark - S+PB and (F) coconut fiber + semi-composted pine bark - $\mathrm{CF}+\mathrm{PB}$, after 240 days of Adenium plants cultivation. 
During the period of seedling cultivation, $\mathrm{pH}$ of pine bark substrate and its mixtures were near to 8.0 (Figure 3 ), which according to Boaro et al. (2014) is common in many organic substrates. They reported the $\mathrm{pH}$ and electrical conductivity presenting values of 7.8 and $0.98 \mathrm{mS} \mathrm{cm}^{-1}$ respectively, for the composted substrate of eucalyptus bark. The $\mathrm{pH}$ of substrates showed an overall small fluctuation during the cycle, tending to decrease after 180 days of culture (data not shown). The acidification of the substrates may have occurred due to the plant growth and electrogenic pump activity, $\mathrm{H}^{+}$-ATPase (YI-YONG et al., 2011). These results are in conformity with Ludwig et al. (2014), who also observed a decrease in $\mathrm{pH}$ of pine bark substrate that turned semi-decomposed at the end of the cultivation cycle of Gerbera jamesonii.
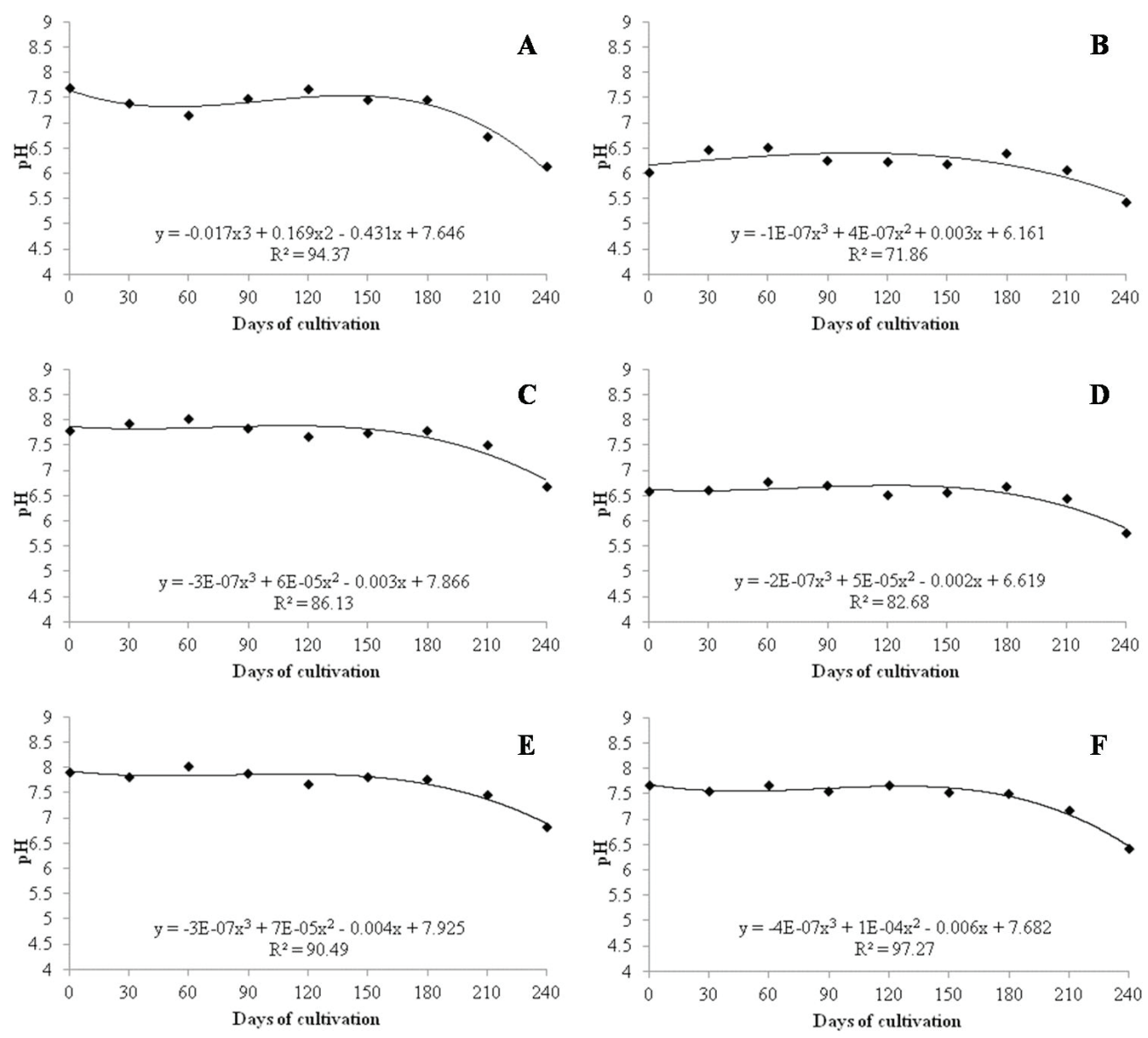

Figure 3 - Variation of $\mathrm{pH}$ on different substrates: (A) sand - S; (B) coconut fiber - CF; (C) semi-composted pine bark - PB; (D) sand + coconut fiber - S+CF; (E) sand + semi-composted pine bark - S+PB and (F) coconut fiber + semicomposted pine bark $-\mathrm{CF}+\mathrm{PB}$, after 240 days of Adenium plants cultivation

It is also noteworthy here that the changes in the substrates $\mathrm{pH}$ can occur even without cultivated plants on it, but only with the water addition to the medium. Boaro et al. (2014) found a pH change in cubic order, when eucalyptus bark substrate was watered for over 80 days. Under these circumstances, it is important to monitor the substrates $\mathrm{pH}$ during the cultivation period, because the $\mathrm{pH}$ is resulted of the relationship between substrate, water and plant.

\section{CONCLUSIONS}

The use of semi-composted pine bark as substrate is recommended for seed germination and seedling growth of desert rose. Although, sand substrate can ensure a good germination for desert rose, but the substrate limits the seedlings growth and reduces the final quality of the seedlings.

\section{AUTHORS CONTRIBUTIONS}

R.C.C.: Creation of the idea, literature review, data collection, laboratory analysis, statistical analysis of the data, and manuscript writing. V.F.: Literature review, data collection, laboratory analysis, manuscript writing. D.U.C.: Literature review, data collection, laboratory analysis, manuscript review. M.A.C.: Literature review, data collection, laboratory analysis, manuscript review. S.R.R.: Obtaining the funding and materials, orientation and coordination of the study. R.T.F.: Creation of the idea, obtaining the funding and materials, orientation and coordination of the study, as well as, important suggestions to the manuscript final version. 


\section{REFERENCES}

ALVES, G.A.C.; FREIRIA, G.H.; FURLAN, F.F.; BERTONCELLI, D.J.; BARBOSA, A.P.; COLOMBO, R.C.; FARIA, R.T.; MESCHEDE, D.K. Pilea microphylla chemical control in desert rose production. International Journal of Current Research, v.8, n.8, p.35624-35627, 2016.

BOARO, V.; SCHWARZ, S.F.; SOUZA, P.V.D.; SOARES, W.; LOUROSA, G.V. Enxofre elementar no manejo do pH de substrato orgânico alcalino. Ciência Rural, v.44, p.2111-2117, 2014. DOI: <http://dx.doi.org/10.1590/01038478 cr20130768>

BRASIL - Ministério da Agricultura, Pecuária e Abastecimento. Manual de análise sanitária de sementes. Brasília: MAPA/Secretaria de Defesa Agropecuária, 2009. 399p.

CABALlERO, R.; ORDOVÁS, J.; PAJUELO, P.; CARMONA, E.; DELGADO, A. Iron chlorosis in gerbera as related to properties of various types of compost used as growing media. Communications in Soil Science and Plant Analysis, v.38, p.2357-2369, 2007. DOI: <http:// dx.doi.org/10.1080/00103620701588494>

CARRIJO, O.A.; LIZ, R.S.; MAKISHIMA, N. Fibra da casca do coco verde como substrato agrícola. Horticultura Brasileira, v.20, n.4, p.533-535, 2002.

COLOMBO, R.C.; FAVETTA, V.; YAMAMOTO, L.Y.; ALVES, G.A.C.; ABATI, J.; TAKAHASHI, L.S.A.; FARIA, R.T. Biometric description of fruits and seeds, germination and imbibition pattern of desert rose [Adenium obesum (Forssk.), Roem. \& Schult.]. Journal of Seed Science, v.37, n.4, p.206-213, 2015. DOI: <http://dx.doi. org/10.1590/2317-1545v37n4152811>

COLOMBO, R.C.; FAVETTA, V.; MELO, T.R.; FARIA, R.T.; SILVA, M.A.A. Potting media, growth and build-up of nutrients in container-grown desert rose. Australian Journal of Crop Science, v.10, n.2, p.258-263, 2016.

DIMMITT, M.; JOSEPH, G.; PALZKILL, D. Adenium: Sculptural Elegance, Floral Extravagance. Tucson: Scathingly Brilliant Idea, 2009. 152p.

KÄMPF, A.N.; TAKANE, R.J.; SIQUEIRA P.T.V. Floricultura: técnicas de preparo de substratos. Brasília: LK, 2006. 132p.
LUDWIG, F.; FERNANDES, D.M.; GUERRERO, A.C.; BÔAS, R.L.V. Características dos substratos na absorção de nutrientes e na produção de gérbera de vaso. Horticultura Brasileira, v.32, n.2, p.184-189, 2014. DOI: <http://dx.doi. org/10.1590/S0102-05362014000200011>

MAGUIRE, J.D. Speed of germination-aid in selection and evaluation for seedling emergence and vigor. Crop Science, v.2, n.1, p.176-177, 1962. DOI: <http://dx.doi. org/10.2135/cropsci1962.0011183X000200020033x>

McBRIDE, K.M.; HENNY, R.J.; CHEN, J.; MELLICH, T.A. Effect of light intensity and nutrition level on growth and flowering of Adenium obesum 'Red' and 'Ice Pink'. HortScience, v.49, n.4, p.430-433, 2014.

PACHECO, M.V.; MATOS, V.P.; FERREIRA, R.L.C.; FELICIANO, A.L.P.; PINTO, K.M. S. Efeito de temperaturas e substratos na germinação de sementes de Myracrodruon urundeuva Fr. All. (Anacardiaceae). Revista Árvore, v.30, n.3, p.359-367, 2006. DOI: <http:// dx.doi.org/10.1590/S0100-67622006000300006>

SANTOS, F.R.P.; CASTILHO, R.M.M.; DUARTE E.F. Caracterização físico-química de sete componentes de substratos recomendados para uso em floricultura. Cultura Agronômica, v.11, p.81-92, 2002.

SCHAFER, G.; SOUZA, P.V.D.; KOLLER, O.C.; SCHWARZ, S.F. Physical and chemical properties of substrates to cultivate seedling of citrus rootstocks. Communications in Soil Science and Plant Analysis, v.39, p.1067-1079, 2008. DOI: <http://dx.doi. org/10.1080/00103620801925547>

SCHAFER, G.; SOUZA, P.V.D.; FIOR, C.S. Um panorama das propriedades físicas e químicas de substratos utilizados em horticultura no sul do Brasil. Ornamental Horticulture, v.21, n.3, p.299-306, 2015.

WAGNER JÚNIOR, A.; SANTOS, C.E.M.; SILVA, J.O.C.; ALEXANDRE, R.S.; NEGREIROS, J.R.S.; PIMENTEL, L.D.; ÁLVARES, V.S.; BRUCKNER, C.H. Influência do pH da água de embebição das sementes e do substrato na germinação e desenvolvimento inicial do maracujazeiro doce. Revista Brasileira de Agrociência, v.12, n.2, p.231236, 2006.

YI-YONG, Z.; JUAN, L.; HOU-QING, Z.; GAN, L.; TING-JUN, D.; QI-RONG, S.; GUO-HUA, X. Involvement of plasma membrane $\mathrm{H}^{+}$-ATPase in adaption of rice to ammonium nutrient. Rice Science, v.18, n.4, p.335-342, 2011. DOI: <https://doi.org/10.1016/S16726308(12)60012-2>. 